\title{
Nutritional status of children under 5 years of age in three hurricane-affected areas of Honduras
}

\author{
Roberto E. Barrios, ${ }^{1}$ James P. Stansbury, ${ }^{1}$ Rosa Palencia, ${ }^{2}$ \\ and Marco T. Medina ${ }^{3}$
}

ABSTRACT Hurricanes and other natural disasters can produce crop destruction, population displacement, infrastructure damage, and long-term public health consequences that include increased malnutrition among the affected populations. This paper presents the results of anthropometric measurements taken of 295 children under 5 years of age from three regions of Honduras that were affected by Hurricane Mitch, a major storm that struck Central America in the fall of 1998. The children in our study were sampled in three shelters in the capital city of Tegucigalpa; in the resettlement zone of Nueva Choluteca, Choluteca; and in the small urban area of Catacamas, Olancho. Our data indicated that, in comparison to the period before the hurricane, there was an elevated prevalence of wasting in all three of the study areas, and that there were also high levels of underweight in the Tegucigalpa and Nueva Choluteca study areas. There were statistically significant differences between the mean values of malnutrition indicators for Catacamas and those for the Tegucigalpa and Nueva Choluteca settlements. These differences suggest that resettled families were confronting a nutritional crisis in July and August of 1999, some 9 months after the hurricane struck.

Hurricane Mitch pounded Honduras from 25 to 31 October 1998, severely impacting various regions of the country. Out of a total population of 5.6 million, the hurricane left 6600 confirmed dead, 8000 to 14000 missing, and drove 2.1 million people from their homes. Damages to infrastruc-

\footnotetext{
University of Florida, Department of Anthropology, Gainesville, Florida, United States of America. Send correspondence to: James P. Stansbury, Department of Anthropology, University of Florida, 1112 Turlington Hall, Gainesville, Florida 32611-7305, United States of America; telephone: (352) 392-2427; e-mail: jstansbu@ufl.edu

2 Clínica Viera, Tegucigalpa, Honduras.

3 Universidad Nacional Autónoma de Honduras, Facultad de Ciencias Médicas, Tegucigalpa, Honduras.
}

ture and industry were estimated at US\$ 1.34 billion (1-3). Tegucigalpa, the capital city, lost 230 factories and workshops. Land erosion severely affected agriculture, and it is estimated that $70 \%$ of the basic grain and export crops were destroyed. Satellite imagery suggested that this was not passing damage, and that the storm's severe impact might compromise future agricultural production and food security in Central America (1).

In addition to the immediate repercussions, natural disasters like Hurricane Mitch may also have substantial secondary public health effects resulting from crop destruction, widespread flooding, and the relocation of affected populations into overcrowded and un- sanitary resettlement areas (4). There is a critical gap in our understanding of the long-term nutrition and health consequences of hurricanes and tropical storms (5), an unmet need that becomes more pressing in light of disasters such as Mitch and the torrential rains and flooding that hit Venezuela in December 1999. Although casualty rates may stabilize during the postdisaster phase, undernutrition is most likely to develop over the long term among affected populations.

This research briefly reports the prevalence of both severe malnutrition and mild-to-moderate malnutrition (MMM) among children under 5 years of age in three hurricane-affected regions of Honduras. Following the infor- 
mation on child nutritional status, we discuss the variation among samples in the three areas and the potential sources of these differences. Children under 5 years of age were specifically chosen because their health status is a sensitive indicator of overall community health, particularly among disadvantaged populations $(4,6,7)$.

\section{MATERIALS AND METHODS}

During July and August of 1999 we collected height, weight, and epidemiological information on 295 children under the age of 5 years: 99 children in the department of Olancho, 96 children in the department of Choluteca, and 100 children from three shelters in Tegucigalpa. Both the Choluteca and Tegucigalpa samples were chosen from resettled populations. Children in the three Tegucigalpa shelters were randomly chosen from a sampling frame provided by the Honduran Red Cross. In Choluteca, participants were chosen from every fifth household in the settlement of Nueva Choluteca. In Olancho, the children were from the small city of Catacamas, with the sample taken from 22 of the town's neighborhoods. Thus, the sample from Catacamas was representative of overall nutritional status in a community moderately affected by the hurricane, while the samples from Tegucigalpa and Choluteca were persons who had been displaced and were those most affected by the hurricane and its aftermath.

Anthropometric measurements of height and weight were taken in conformity with standard techniques (8). The child's age was confirmed through birth or vaccination certificates in 272 of the cases. The remaining 23 cases could not produce a formal means of age confirmation and were included only when the primary caretaker could accurately respond to a number of questions concerning the child's date of birth. Height, or recumbent length for children under 2 years of age, was measured using a stadiometer (Perspective Enterprises, Portage, Michigan, United States of America).
Smaller children were weighed using a hanging scale (Itac, Ellicott City, Maryland, United States), and larger children were weighed using a foot scale (Health o meter ${ }^{\circledR}$, Denver, Colorado, United States).

The measurements were collected by three field researchers: a nutritionist, a registered nurse, and an anthropologist. Study reliability was determined from a subsample of 30 repeat observations. Reliability and technical error of measurement (TEM) were calculated in line with Ulijaszek (9).

In the field we used a portable computer and Epi Info software (Centers for Disease Control and Prevention, Atlanta, Georgia, United States) to perform a preliminary analysis of the anthropometric data, including the calculation of standardized scores with respect to the National Center for Health Statistics (NCHS) reference, a growth standard intended for international use (6). We conducted further analyses at the University of Florida using SAS STAT software (SAS Institute, Cary, North Carolina, United States). These analyses included chisquare tests of independence for the prevalence results, and analysis of variance (ANOVA) and $t$ tests to compare means of the anthropometric indices for the three different areas.

\section{RESULTS}

Our anthropometric results reflect adequate levels of interobserver reliability and reduced measurement error. The calculated TEMs for height/recumbent length and for weight were $0.44 \mathrm{~cm}$ and $0.16 \mathrm{~kg}$, respectively. Reliability for height was $99.8 \%$, and the figure for weight was $99.5 \%$.

Table 1 shows the prevalence of severe malnutrition and of mild-tomoderate malnutrition (MMM) as measured by height-for-age $z$ scores (HAZ), weight-for-height $z$ scores (WHZ), and weight-for-age $z$ scores (WAZ), described as stunting, wasting, and underweight, respectively. To make comparisons we obtained malnutrition prevalence information from studies done in Honduras in the years before Hurricane Mitch, from 1987 through 1996 (Table 1).

Overall, the prevalence levels of mild-to-moderate stunting, wasting, and underweight were higher in the temporary settlements of Tegucigalpa and Nueva Choluteca than they were in the Catacamas community sample. Chi-square analysis indicated there was a statistically significant difference in the prevalence of stunting and underweight among the three regions $(P<0.01)$. Differences in the prevalence of wasting among the three samples were not statistically significant, despite the elevated prevalence of low weight-for-height in the samples in the temporary settlements in Tegucigalpa and Nueva Choluteca.

Table 2 shows the means for anthropometric indicators in the three samples. The nutritional status of children in Catacamas was better on average than it was for the children studied in Nueva Choluteca and in Tegucigalpa, for all three anthropometric indices. Tested with ANOVA, differences among the areas were significant for all three indices. Additionally, $t$ tests indicated statistically significant differences between Nueva Choluteca and Tegucigalpa for mean WHZ ( $P=0.0373)$ and between Nueva Choluteca and Catacamas for the same indicator $(P=0.0043)$. The significantly lower average weightfor-height score and elevated prevalence of wasting in Nueva Choluteca underline the acute nutritional emergency faced by those resettled in this area at the time of our survey.

\section{DISCUSSION}

The elevated levels of stunting, wasting, and underweight found in the Nueva Choluteca and Tegucigalpa settlement samples indicate that these populations were confronting severe chronic and acute assaults on their nutritional status 9 months after Hurricane Mitch. The difficult nutritional circumstances of those displaced by the hurricane are also demonstrated by the $z$-score means for the 
TABLE 1. Prevalence (percentage) of severe malnutrition and mild-to-moderate malnutrition among Honduran children under the age of 5 years, 1999 study versus earlier surveys ${ }^{a}$

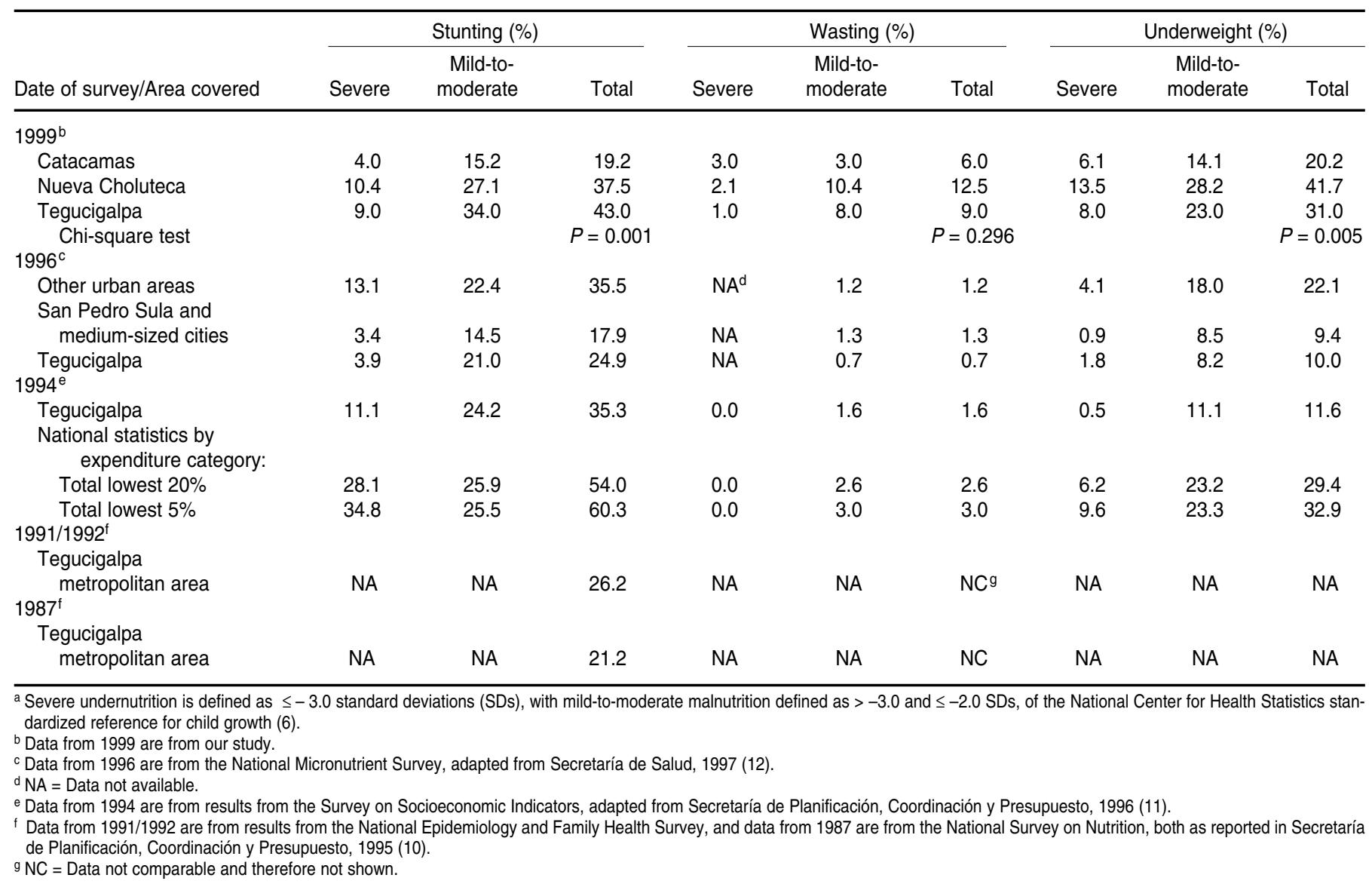

two samples of resettled populations versus the scores for the children in Catacamas.

Additional information to compare nutritional status comes from a series of health and economic surveys conducted in Honduras between 1987 and
1996 (10-12). In these surveys, the national-level statistics showed minor changes over time. However, regionally disaggregated data demonstrated a significant worsening of chronic undernutrition, as measured by stunting, in several areas, including Tegucigalpa.

TABLE 2. Mean $z$ scores and standard deviation (SD) for anthropometric indices at three study sites in Honduras, 1999a

\begin{tabular}{|c|c|c|c|c|c|c|}
\hline \multirow[b]{2}{*}{ Study site } & \multicolumn{2}{|c|}{ HAZ } & \multicolumn{2}{|c|}{ WHZ } & \multicolumn{2}{|c|}{ WAZ } \\
\hline & Mean & SD & Mean & SD & Mean & SD \\
\hline Catacamas & -1.00 & 1.18 & -0.30 & 1.16 & -0.86 & 1.32 \\
\hline Nueva Choluteca & -1.62 & 1.25 & -0.78 & 1.15 & -1.58 & 1.42 \\
\hline Tegucigalpa & -1.69 & 1.05 & -0.43 & 1.17 & -1.35 & 1.19 \\
\hline Analysis of variance & \multicolumn{2}{|c|}{$F=10.5, P<0.001$} & \multicolumn{2}{|c|}{$F=4.40, P=0.013$} & \multicolumn{2}{|c|}{$F=7.62, P<0.001$} \\
\hline
\end{tabular}

${ }^{a}$ Indicated $z$ scores are height-for-age (HAZ), weight-for-height (WHZ), and weight-for-age (WAZ).

Perhaps the most informative comparison comes from looking at data collected in the Tegucigalpa metropolitan area before and after Hurricane Mitch. Stunting increased from 1987 to 1994. During the mid-1990s, however, both stunting and wasting declined substantially (Table 1).

Our Tegucigalpa 1999 sample showed prevalences for moderate stunting and for wasting that were notably higher than those in any of the surveys done before the hurricane. Nevertheless, it is important to remain cautious when making such comparisons for the Tegucigalpa area, since the surveys done before the hurricane involved an economically heterogeneous sample, while the survey in the post-Mitch Tegucigalpa shelters was done with a very disadvantaged segment of the population. 
In addition, data from our three sites and information from the earlier surveys in Honduras are difficult to compare due to differences in the presentation of survey results. For example, national surveys done in 1987 and in $1991 / 1992$ disaggregated the data by region (only Tegucigalpa metropolitan area data shown in Table 1). In contrast, survey results from 1994 and 1996 were reported in clusters of areas with similar demographic profiles (small urban areas, medium-sized cities, etc.).

An alternative comparison comes from looking at the 1994 Survey on Socioeconomic Indicators (11). As shown in Table 1, that survey disaggregated national-level malnutrition prevalence by household expenditure levels. When compared to groups with the lowest $20 \%$ and $5 \%$ of expenditures in that 1994 survey, our samples showed less stunting, comparable levels of underweight, and elevated levels of wasting. The aggregate national statistics from 1994 probably indicate a high prevalence of stunting due to an overrepresentation of poor rural children, who have typically been characterized by higher levels of chronic undernutrition than urban children (10).

Wasting was dramatically higher in all three of our 1999 study areas than had been found in the earlier surveys.
For example, in the 1996 National Micronutrient Survey, $38.5 \%$ of sampled children ages 12 to 71 months were stunted and $24.5 \%$ were underweight, but only $1.5 \%$ were wasted (13). While earlier studies emphasized the difficulties facing rural Honduran children, our research shows clearly the new plight of the urban poor in resettlement areas.

Taken together, these various data are a clear indication of the levels of malnutrition triggered by Hurricane Mitch, particularly among children who were resettled. These difficulties in child nutrition and health parallel what Johnston has termed an "urban disadvantage" in periurban areas of Guatemala and elsewhere (14-16).

In general, the processes of resettlement and reconstruction do not automatically guarantee improvements in the lives of affected populations. Food insecurity, economic marginalization, and social disruption are just a few of the risks identified with community resettlements the world over, according to Cernea (17) and other researchers. ${ }^{4}$ Hurricane Mitch and its

\footnotetext{
4 Ault, SK. The health effects of involuntary resettlement: status of present knowledge and needs assessment. Presentation to the Task Force on Involuntary Resettlement, American Anthropological Association, Washington, D.C., 31 July 1989.
}

aftermath have destroyed productive agricultural land, produced food insecurity, and led to vulnerabilities for resettled populations, all creating a substantial challenge for people's health in the midst of the reconstruction efforts. In Honduras, there is a clear need for continued nutritional surveillance to monitor levels of malnutrition and identify risk factors among the hurricane-affected population.

Acknowledgments. The authors wish to thank the families in Honduras who participated in this study. Funding was provided by the International Hurricane Center at Florida International University. PREDISAN, through the efforts of Doris Clark and Dr. Amanda Madrid, assisted with the work in Catacamas. Carmen Rojas assisted with data collection in Catacamas. In Nueva Choluteca, assistance with sampling was provided by Dr. Sulema Sambrano of the Honduran Secretariat of Health. The Honduran Red Cross provided assistance in Tegucigalpa. The authors thank two anonymous reviewers of an earlier draft of this paper, as well as the Honduran Institute of Anthropology and History, which recognized the researchers as associate investigators.

\section{REFERENCES}

1. Pan American Health Organization. Impact of Hurricane Mitch on Central America. Epidemiol Bull 1998;19(4):1-13.

2. Alcaldía Municipal del Distrito Central. Los daños a la capital en cifras. Tegucigalpa, Honduras: AMDC; 1999.

3. Asociación de Municipalidades Hondureñas. Reubicación y construcción de Morolica. Tegucigalpa, Honduras: AMH; 1999.

4. Toole MJ, Waldman RJ. The public health aspects of complex refugee situations. Annu Rev Public Health 1997;18:283-312.

5. Malilay J. Tropical cyclones. In: Noji EK, ed. The public health consequences of disasters. New York: Oxford University Press; 1997. pp. 207-227.

6. World Health Organization. Energy and protein requirements: report of a joint $\mathrm{FAO} /$
WHO/UNU expert consultation. Geneva: WHO; 1985.

7. de Onis M, Monteiro C, Akre J, Glugston G. The worldwide magnitude of protein-energy malnutrition: an overview from the WHO Global Database on Child Growth. Bull World Health Organ 1993;71(6):703-712.

8. Lohman TG, Roche AF, Martorell R. Anthropometric standardization reference manual. Champaign, Illinois, United States of America: Human Kinetics Books; 1991.

9. Ulijaszek SJ. Anthropometric measures. In Margetts BM, Nelson M, eds. Design concepts in nutritional epidemiology. New York: Oxford University Press; 1997. pp. 289-311.

10. Honduras, Secretaría de Planificación, Coordinación y Presupuesto. Informe de seguimiento y evaluación en salud y nutrición: es- tado de los principales indicadores a nivel regional, 1988-1993. Tegucigalpa: SECPLAN; 1995.

11. Honduras, Secretaría de Planificación, Coordinación y Presupuesto. Salud y nutrición: un estudio de las Encuestas de Hogares. Tegucigalpa: PROGRAFIC; 1996.

12. Honduras, Secretaría de Salud, Subsecretaría de Riesgos Poblacionales. Encuesta Nacional sobre Micronutrientes: informe ejecutivo. Tegucigalpa: Secretaría de Salud; 1997.

13. Nestel P, Melara A, Rosado J, Mora JO. Undernutrition among Honduran children 12-71 months old. Rev Panam Salud Publica/Pan Am J Public Health 1999;6(4):256-265.

14. Johnston FE. The urban disadvantage in the developing world and the physical and mental growth of children. In: Schell LM, Smith M, 
Bilsborough A, eds. Urban health and ecology in the Third World. Cambridge: Cambridge University Press; 1993. pp. 26-37.

15. Johnston FE, Low SM. Children of the urban poor: the sociocultural environment of growth, development, and malnutrition in Guatemala City. Boulder, Colorado, United States: Westview Press; 1995.
16. Johnston FE. Growth faltering and catch-up growth in relation to environmental change in children of a disadvantaged community from Guatemala City. Am J Hum Biol 1995;7: 731-740.

17. Cernea M. The risks and reconstruction model for resettling displaced populations. World Development 1997;25(10):1569-1587.
Manuscript received 13 January 2000. Revised version accepted for publication on 10 July 2000

RESUMEN Los huracanes y otros desastres naturales pueden destruir cosechas, desplazar a poblaciones enteras, causar daños infraestructurales y acarrear consecuencias a largo plazo para la salud pública, entre ellas un aumento de la desnutrición en las poblaciones afectadas. Este trabajo presenta los resultados de las mediciones antropométricas de 295 niños menores de 5 años de tres zonas de Honduras que fueron azotadas por el huracán Mitch, tempestad que azotó Centroamérica en el otoño de 1998. Los niños que participaron en nuestro estudio provinieron de tres alojamientos provisionales, uno en la capital del país, Tegucigalpa; otro en la zona de asentamiento para refugiados de Nueva Choluteca, Choluteca; y otro en la pequeña zona urbana de Catacamas, Olancho. Según indican nuestros datos, en comparación con el período anterior al huracán, la frecuencia de emaciación en las tres zonas fue alta, como también lo fue la de peso subnormal en las zonas de estudio de Tegucigalpa y Nueva Choluteca. Hubo diferencias estadísticamente significativas entre los valores promedio de los indicadores de desnutrición en Catacamas y los de los asentamientos de Tegucigalpa y Nueva Choluteca. Estas diferencias indican que las familias desplazadas enfrentaban una crisis nutricional en julio y agosto de 1999, alrededor de 9 meses después de la llegada del huracán.

\section{Estado nutricional de niños azotadas por un huracán}

Recent sociocultural change will raise the probability of incongruity between the culture of the migrant and the social situation in which he lives. Such incongruities as occur will place excessive adjustive burdens on the social groups in which the migrant interacts and on the personality system of individual migrants. Insofar as these stresses are not absorbed by the small group systems and/or the personality system, recent migrants to an industrial milieu are likely to manifest increased rates of psychological, somatic, and social ill health.

[Los recientes cambios socioculturales aumentarán la probabilidad de discrepancias entre la cultura del emigrante y el medio social en el que vive. Tales discrepancias impondrán cargas de adaptación excesivas a los grupos sociales con los que interactúa el emigrante y a su personalidad individual. En la medida en que estas dificultades no son asimiladas por el sistema del grupo social inmediato y la personalidad, es muy probable que se produzca un aumento en las tasas de trastornos psicológicos, somáticos y sociales entre las personas que acaban de migrar a un ambiente industrial.]

John Cassel and Herman A. Tyroler "Epidemiological studies of culture change" Archives of Environmental Health, 1961;3:31-39 